\title{
Persisting attachment to physical cultural goods
}

La persistance de l'attachement aux biens culturels physiques

\section{Quentin Gilliotte}

Translator. Katharine Throssell

\section{(2) OpenEdition}

\section{Journals}

Electronic version

URL: https://journals.openedition.org/bssg/885

DOI: $10.4000 /$ bssg.885

ISSN: 2490-9424

\section{Publisher}

Université Paris Lumières

Electronic reference

Quentin Gilliotte, "Persisting attachment to physical cultural goods", Biens Symboliques / Symbolic Goods [Online], 9 | 2021, Online since 27 December 2021, connection on 13 January 2022. URL: http:// journals.openedition.org/bssg/885 ; DOl: https://doi.org/10.4000/bssg.885

This text was automatically generated on 13 January 2022.

Biens Symboliques / Symbolic Goods 


\section{Persisting attachment to physical cultural goods}

La persistance de l'attachement aux biens culturels physiques

\section{Quentin Gilliotte}

Translation : Katharine Throssell

Fig. 1.

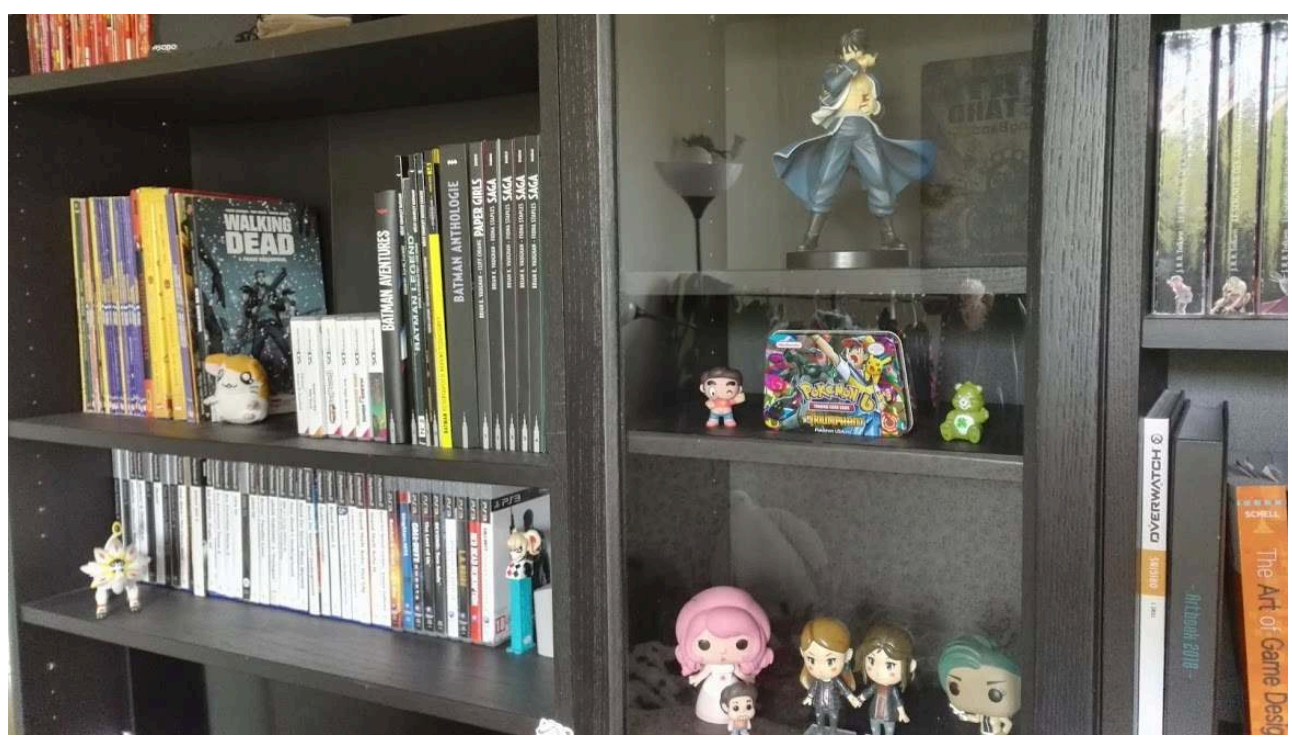

Étagère de livres, comics, jeux vidéo et figurines

(c) Quentin Gilliotte

1 Why do we buy and use CDs, DVDs, or vinyl records today? Why take the time to set up a record player and carefully place the needle on an LP? Why do we collect DVD boxed sets of our favourite TV series?

2 In terms of the consumption of cultural goods, there is no doubt that there has been a shift from the physical to the digital. The sales of CDs and DVDs have plummeted, while 
downloads and streaming have successively taken their place (Gfk 2020; SNEP 2019). In the music and video sectors, the turning point occurred in the year 2018-2019, when the sales of digital music exceeded that of physical recordings in France due to audio streaming, and in the video market, de-materialised consumption totalled more than $60 \%$ of the market.

Paradoxically, despite of the digitalisation of practices, several phenomena show that there is a persistence, and sometimes even a revival, of the consumption of physical cultural goods. Thus, 53.2 million DVDs were bought in 2018 in France (Gfk 2019). In the same year, more than 3.5 million vinyl records were bought, compared to 3.15 in 2017 (an 11-point increase, SNEP 2019), representing more than $20 \%$ of the market for physical music. CD sales in the same year totalled more than 200 million euros (SNEP 2018). However, this data only takes into account recent acquisitions and ignores the sale of second-hand cultural goods, whether cassette tapes, Super Nintendo games, laser-discs, and other more or less vintage formats that find a home in the collections of afficionados. Moreover, there are few statistical studies that provide information about the way physical goods accumulated in the past are still being used.

Two discourses are often associated with this balance between the physical and the digital. On the one hand, digital media is centred on a dual promise of accessibility. The plethoric offer seems infinite and music catalogues progressively gain a colossal number of references, between new productions and the acquisition of already existing licences. Moreover, the digital offer presents that other advantage of significantly reducing the constraints in access to goods. Listening to music or watching films and series via Deezer, YouTube, Netflix or similar services can be done nearly anywhere, anytime, and on almost any technological device (desktops, laptops, telephones, tablets). Why would digital goods not be preferred? Yet the de-materialisation of cultural goods has also been associated with a "dispossession"; in the digital world we no longer seem to possess cultural goods. Certain collectors, amateurs, or experts may lament the loss of the object, a loss of affection, attachment, in itself a sign of "impossession" (Chantepie 2017; Petrover 2015).

5 Although several studies have shown the importance of paper books and the sensory aspect of reading (Guittet 2020), the importance of materiality for media (music, series, films, and video games) has been much less covered, and studies on the digital shift have partly obscured the question on the perpetuation of previous formats. Thus, the use of digital media has been widely studied in recent years (Béchec, Crépel, Boullier 2014; Beuscart 2017; Granjon \& Combes 2008; Le Guern 2016; Perticoz 2009), while studies on the persistence of physical goods are much more rare. The few that have been published (Chaney 2009; Legault-Venne, Laplante, Leblanc-Proulx, Forest 2016; Magaudda 2011; Nguyen, Dejean, \& Moreau 2014) primarily focus on music. So, what is the place of physical cultural goods today?

6 This article draws on more than sixty in-depth semi-directive interviews, from a population that is diversified in terms of age, social background, level of education and place of residence. It also draws on the results of a questionnaire administered to more than 2000 respondents. Having designed the questionnaire, we called on a survey institute (Médiamétrie) to administer the questionnaire by quota based on variables measuring education, age, sex, and socio-professional category (SPC). The data from the questionnaire were analysed using multiple correspondence analysis (MCA) and 
ascending hierarchical classification (AHC), which will not be discussed in this article but which contributed to the diversification of profiles included. ${ }^{1}$

\section{Understanding reflexive abilities in the face of heterogenous practices}

7 The interviews were conducted in two stages, with a group of thirty interviewees each time. The first phase of the interviews allowed me to test certain hypotheses, validate certain positions in the choice of the issues covered, and prepare the construction of the quantitative study. Among the 2000 who responded to the questionnaire, 500 accepted additional interviews in their home. In the second wave of interviews it was therefore possible to focus on the recruitment of individuals with profiles that were underrepresented in the first wave, particularly individuals who were not active in the consumption of cultural goods and/or from working class backgrounds.

Table 1. Distribution of participants in the qualitative study by sex

\begin{tabular}{|l|l|l|}
\hline Men & Women & Total \\
\hline 29 & 34 & 63 \\
\hline $46 \%$ & $54 \%$ & $100 \%$ \\
\hline
\end{tabular}

Source: Quentin Gilliotte

Table 2. Distribution of participants in the qualitative study by age

\begin{tabular}{|l|l|l|l|l|l|l|}
\hline $\mathbf{1 8 - 2 5}$ years & $26-35$ years & $\mathbf{3 6 - 4 5}$ years & $\mathbf{4 6 - 5 5}$ years & $56-65$ years & $\mathbf{6 6}$ and over & Total \\
\hline 10 & 18 & 9 & 8 & 14 & 4 & 63 \\
\hline $16 \%$ & $29 \%$ & $14 \%$ & $13 \%$ & $22 \%$ & $6 \%$ & $\mathbf{1 0 0 \%}$ \\
\hline
\end{tabular}

Source: Quentin Gilliotte

Table 3. Distribution of participants in the qualitative study by SPC

\begin{tabular}{|l|l|l|l|l|l|l|l|l|}
\hline $\begin{array}{l}\text { Individual } \\
\text { farmers }\end{array}$ & $\begin{array}{l}\text { Tradesmen, } \\
\text { shopkeepers, } \\
\text { business } \\
\text { owners }\end{array}$ & $\begin{array}{l}\text { Managers } \\
\text { and senior } \\
\text { intellectual } \\
\text { professions }\end{array}$ & $\begin{array}{l}\text { Intermediary } \\
\text { professions }\end{array}$ & $\begin{array}{l}\text { Workers } \\
\text { and } \\
\text { employees }\end{array}$ & Students & Retirees & $\begin{array}{l}\text { Inactive } \\
\text { (ex.retirees } \\
\text { and } \\
\text { students) }\end{array}$ & Total \\
\hline 1 & 9 & 6 & 6 & 16 & 7 & 8 & 10 & $\mathbf{6 3}$ \\
\hline $2 \%$ & $14 \%$ & $10 \%$ & $10 \%$ & $25 \%$ & $11 \%$ & $13 \%$ & $16 \%$ & $\mathbf{1 0 0 \%}$ \\
\hline
\end{tabular}

Source: Quentin Gilliotte 
Table 4. Distribution of participants in the qualitative study by simplified SPC

\begin{tabular}{|l|l|l|l|l|l|l|}
\hline SPC & $\begin{array}{l}\text { Middle SPC, } \\
\text { public sector }\end{array}$ & $\begin{array}{l}\text { Middle SPC, } \\
\text { private sector }\end{array}$ & SPC+ & $\begin{array}{l}\text { No professional } \\
\text { activity }\end{array}$ & $\begin{array}{l}\text { Of which, } \\
\text { students }\end{array}$ & Total \\
\hline 11 & 10 & 13 & 10 & 19 & 7 & 63 \\
\hline $17 \%$ & $16 \%$ & $21 \%$ & $16 \%$ & $30 \%$ & & $\mathbf{1 0 0 \%}$ \\
\hline
\end{tabular}

Source: Quentin Gilliotte

8 The results of the quantitative study provided first-hand contextual data for the question on the use of physical and digital cultural goods. Many studies emphasize the idea that a digital regime is "in the sense of a relatively unstructured configuration of elements, less rigid than the terms 'institution' or 'era', but including both material and non-material elements, with sufficient shared characteristics to produce a systemic effect. The digital regime is thus both a discourse on digital media and the everyday use of this technology." (Prior 2012) This notion of a digital regime is relevant for describing a certain number of situations, and particularly a process that is being transformed. However, the analysis of the quantitative data shows that we are clearly in a "mixed" regime, within which individuals mobilise both physical and digital goods.

Respondents were therefore asked to indicate which kinds of media they had used in the last 30 days, whether physical (CD, DVD, vinyl records, cassette tapes, laser-discs, video games (boxes or cartridges)) or digital (streaming or downloading). Although the use of digital goods drops dramatically as the age of respondents increases, the use of physical goods proves more "resistant". Where $37 \%$ of 50-64 year olds had used a CD in the last 30 days, only $21 \%$ of $15-24$ year olds had done so in the same period. The gap is even smaller for DVDs, respectively $27 \%$ and $34 \%$ for the same age groups. How can we explain this persistent use of physical goods even among the youngest age groups?

In terms of usage, this study clearly shows that being passionate about a particular area goes hand in hand with the use of several kinds of media, physical and digital. One of the variables in the questionnaire allows interviewees to declare the level of interest in various areas. Thus, respondents who say they are "passionate" about music ( $20 \%$ of the study population) are also more likely than the general population to say they have used all the varieties of recorded music proposed, whether physical or digital, over the last 30 days, but particularly streaming ( +22 points), CDs ( +15 points), and downloads $(+14$ points), but also to a lesser extent vinyl records ( +7 points) and audio cassettes $(+3$ points). Similarly, individuals who say they are passionate about films use many more different kinds of audio-visual sources, particularly streaming (+12), downloads (+9), and DVDs (+8), but VHS remains very marginal. The use of physical goods is particularly visible among individuals who are more engaged in the different areas studied (films, series, music, and video games in particular).

Beyond the question of usage is the idea of an attachment to these things in themselves. One variable allows us to determine which format respondents are particularly attached to, out of a list of a more than a dozen forms of audio-visual goods, both physical and digital. This first observation is that the attachment to cultural goods emerges almost exclusively for physical goods. Attachment to books as 
an object is undeniable, $38 \%$ of respondents say it is the medium they are the most attached to. After books come records (12\%), CDs (9\%), and DVD/BluRay (6\%), above all other kinds of goods. The fact that the question asked for a single preference should not obscure the fact that among respondents who say they are attached to books there is also a diverse range of attachment to other kinds of cultural goods.

In looking at this attachment to physical media-cultural goods, a reading in terms of socio-professional categories brings retirees and students particularly to the fore, groups that are both very age-dependent. There is however a slight overrepresentation of employees among those who say they are attached to CDs ( +5 points) and DVD/ BluRay. Education does not appear to have a substantial impact, with less than $3 \%$ difference between respondents with more than 4 years post-secondary education and those with less than secondary, whether for CDs, DVDs-BluRay or records. This result runs completely counter to data concerning reading and attitudes towards books as an object, in which differences in terms of SPC or education level are much more marked (14 points between SPC + and SPC -; 21 points between individuals with less than secondary education, and those with more than 4 years post-secondary) and clearly show a greater attachment to books as an object among the upper classes.

However, there are two variables that have a strong influence on attachment to physical media- cultural goods. Firstly, there is the variable that measures declared interest in a particular sphere, because respondents who say they are "passionate" about music are overrepresented among those who say vinyl records are the medium they are most attached to (21\%). The same is true to a lesser extent for CD's (14\%). Similarly, those who are "passionate" about films are overrepresented among those who say they are particularly attached to DVD's and BluRays (14\%).

The other key variable is age. We observe a genuine correspondence between the age of the respondents and their preferred medium for cultural goods, particularly for those that were common in their youth. Thus, attachment to CDs is overrepresented in the 25-34 year old age group (16\%), and under represented among the over 65 year olds (4\%). Similarly, attachment to records is overrepresented among the 50-64 year olds (19\%), and under represented among the 15-24 year olds (9\%). There is a clear combined effect of age and declared interest in a domain, because cultural passions with the notable exception of books - are highly visible in younger groups. Indeed, level of education or SPC play a smaller role for those who say they are "passionate" about music, films, or series. Individuals in upper classes prefer to describe themselves as "amateurs" in general in a wider range of different areas, possibly a sign of omnivorism (Peterson 2004), here applied to an investment in different sectors. Passion, both in reality and in representations, tends to be associated with more juvenile characteristics even when it is observed in adults (Maigret 2002). Sometimes it is also considered lower class, possibly in opposition to the figure of bourgeois asceticism (Bourdieu 1987). ${ }^{2}$

Another one of the questions in the quantitative study asked respondents to situate themselves on a Likert scale in response to the following prompt: "in spite of digital media, it is important to possess physical goods." Nearly half of respondents (47\%) agreed strongly with this statement, and only $5 \%$ strongly disagreed. We can see the same results as those presented above, where SPC or education appear less relevant, with the importance being on the variables of age and above all interest in particular spheres. It was primarily respondents who are passionate about music, series, or films 
who are overrepresented among those who "strongly agree" (+13 points). Overall, it is difficult to consider this use of physical media-cultural goods in light of the variables that are typically considered to be indicators of the amount of capital an individual possesses, and particularly cultural capital.

In terms of the qualitative study, the observation is relatively similar. The interviewees, who were selected for this article among the 63 people interviewed, are those who were emotionally invested in material forms of media-cultural consumption. This tends to exclude the more working class categories who might be more invested in media consumption, particularly television, but also the interviewees from the upper classes who tend to be more focused on books, which probably remain the form of domestic cultural consumption that is considered the most legitimate. Overall, in light of both the qualitative and quantitative fieldwork, we can hypothesise that this attachment to media-cultural goods is more likely to be the realm of individuals who are in an intermediary position in the social hierarchy and for whom this attachment to physical goods is more transversal, but also covers content that we know to be socially differentiated.

This plays out against the background of the eternal debates between sociologists of culture on the transformations of cultural hierarchies, whether in terms of the increase in dissonance and the decrease in literary and artistic legitimacy (Lahire 2006), the rise of the omnivore/univore model (Peterson 2004), and various different amendments to the Bourdieusian model, particularly in terms of cultural eclecticism (Coulangeon 2011). Some even see a $90^{\circ}$ shift in the space of lifestyles presented in Distinction, heralding the end of classical cultural hierarchy and the emergence of an intra-genre cultural hierarchy (Glevarec 2005). Although the terms or concepts have increased in number, the fundamental observation of a heterogenization of value regimes in terms of cultural consumption has densified and complexified the reading of intermediary profiles occurring at the crossroads, which accumulate both highly legitimate and highly illegitimate practices. In addition, many studies emphasize the increasing importance of age as a variable, which sometimes has more impact on the distribution of practices than other socio-demographic variables (Glevarec \& Pinet 2013; Octobre 2014; Octobre, Détrez, Mercklé, Berthomier 2011; Pasquier 2005).

In this context, how can we understand the use of physical cultural goods within a population marked by a strong heterogeneity of practices and tastes? It would be possible to conduct an analysis in terms of dispositions (Lahire 2006) in order to analyse the conditions of individuals' cultural socialisation, but which would encourage (in the choice of qualitative methods) the use of life histories as a tool for collecting data, and portraits as an analytic tool (Lahire 2008, 2019). However, the interviews conducted here are particularly focused on individuals' "art of doing" (Certeau 2011) and shed light on the broad diversity and complexity of the reflexive abilities of individuals who for the most part are neither completely dominant, nor completely dominated. The interviews show that these individuals are aware of these issues of legitimacy and are led to situate themselves in relation to these conventions, in particular because they are also familiar with major sociological theories - more or less vulgarised - which Danilo Martuccelli calls the "sociologisation" of individuals (2010) and Cyril Lemieux describes as the "performativity of sociology" (2018). is situated within pragmatic sociology that aims to unpack the modalities of 
individuals' tastes and attachments to things according to different grammars (Lemieux 2009) as social situations consisting in a range of rules to follow for "correct" behaviour, but from which individuals may stray. According to this perspective, individuals' actions subscribe to a form of rationality depending on the grammar in which they are embedded, which means there is always a reason for action. In this respect, we adopt pragmatic sociology's principle of internalism (Lemieux 2018), which is similar to the comprehensive Weberian approach. They particularly share the fact that they "take seriously the way in which actors define themselves, what is important and what is not, or even what is real and what is not" (ibid.: 19). The goal is to identify practices, representations, discourses on cultural goods, at the crossroads between routines (not as repetition but as "the reinforcement of a tendency for action" p.41) and programmes "that primarily characterised by the fact that they lead individuals to do what they would otherwise not necessarily do" (p.44). Studies in the sociology of culture have more than demonstrated the role of primary and secondary socialisation (Eloy 2014, 2015; Lahire 2006; Mauger, Poliak, Pudal 2010; Octobre \& Berthomier 2012) in the development of tastes and practices, and the power relations that run through cultural consumption. The goal here is more to understand how the sensory properties of an object contribute to the activity of an amateur (Hennion 2004, 2009).

We already know that format has an impact on how individuals develop an attachment to and use cultural goods. Research by Antoine Hennion and Sophie Maisonneuve (Hennion, Maisonneuve, Gomart 2000) has demonstrated, for example, how the format of a CD changes the experience of music, through a phenomenon that the authors call "discomorphose": the shift from live music to the album as a reference, which introduced the idea of coherence within an album, and the order of the songs. Then Granjon and Combes demonstrated the effects of "numerimorphose" (digital morphosis) of consumer practices (2008) with the rise of fragmented listening, switching, and playlists. Like for audio-visual goods, owning the DVD of a film and watching the same film on a streaming platform are two different kinds of experience that have different meanings for amateurs. Why do some individuals use both digital and physical formats? How can we explain the persistence of some physical formats in spite of the rise of digital cultural goods?

In this article we will see that the use of physical goods is articulated around two opposing poles, ease and constraint. On the one hand, these physical formats provide practical advantages that in many cases encourage interviewees to use them on an everyday basis, whether re-consuming them, having them on hand, or sharing them. The immediate availability of physical formats in the domestic space is often presented as a decided advantage. Where these objects are available, they can be easily taking up, handled, and used. Moreover, they give interviewee's the feeling they are genuinely owned, unlike digital goods. This is also what emerges from the qualitative study in which $84 \%$ of people questioned agreed or strongly agreed with the following statement "with digital goods you don't really possess the cultural goods that you buy". Yet there are some goods that "must" be owned because they are particularly important in the eyes of certain individuals and because the materiality of the object sometimes cannot be replaced by digital goods.

On the other hand, these goods also present a certain number of constraints that have been made virtues, and now contribute to the pleasure of their consumption, recreating the rarity and singularity of the experience. Physical acquisition of cultural 
goods continues in a number of specific cases that depend neither on technical constraints, nor skills, nor simple phenomena of circulation, or gifts. They respond to specific needs in certain situations and often prove complementary to the digital format. The reflexive work of individuals can be seen here; they seek to increase their pleasure, finding the socio-technical combinations that have the most effect on them, providing access to a form of singularisation of consumer experience. This singularisation primarily occurs through a sensory relationship with cultural goods (through touch, smell, place in the domestic space) and through forms of ritualisation of acquisition and use.

\section{Advantages of physically possessing cultural goods}

Fig. 2.

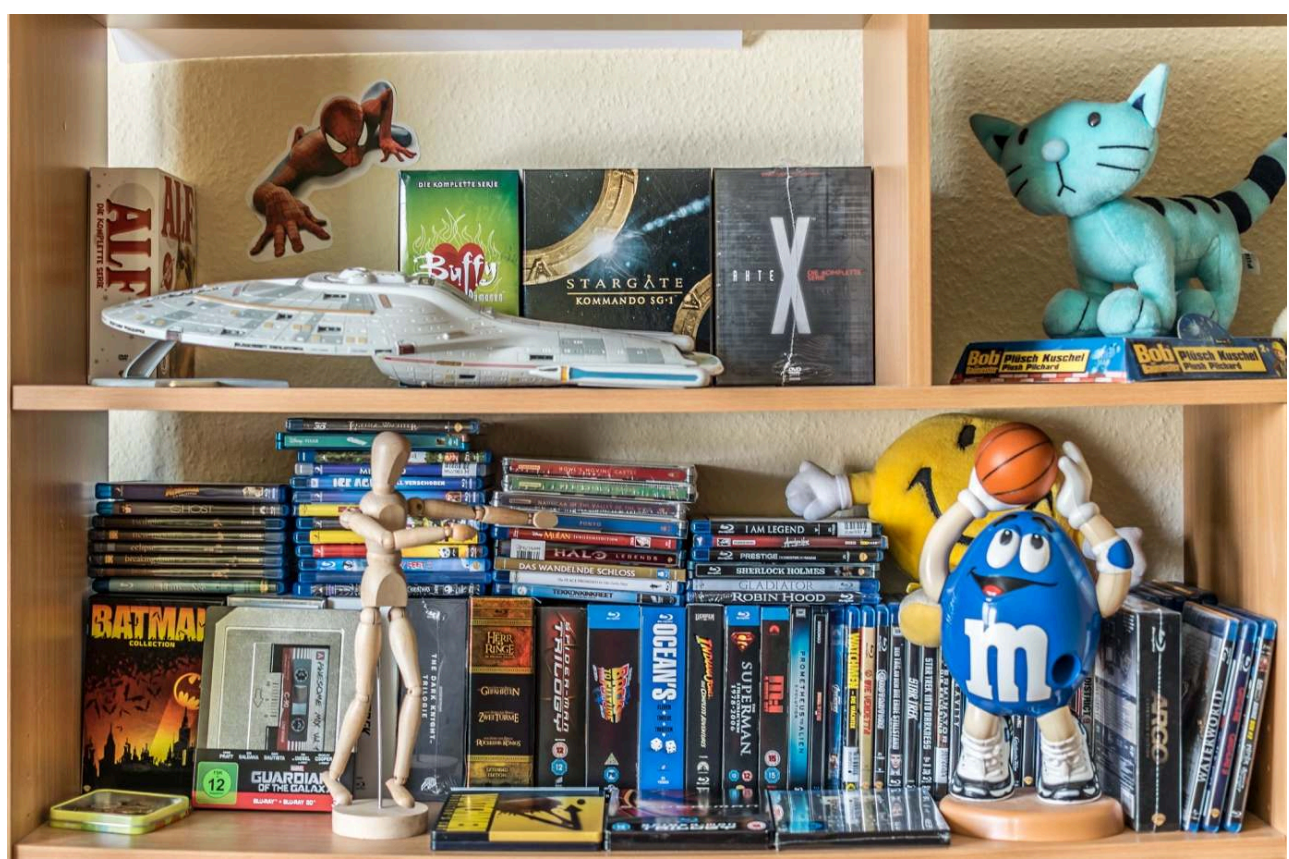

Blu-Ray bookshelf

\section{(C) J. Triepke. Licence CC BY 2.0}

In this section we will see that the acquisition and use of physical goods is partly due to the advantages they provide. Even when digital goods are designed to facilitate access and consumption, physical goods are often preferred because they facilitate certain types of usage, or manipulations. From a dispositionalist perspective we could describe this as a "practical relation" to the cultural consumption of physical goods (Bakhtine, Todorov, Aucouturier 1984; Lahire 2008). In the instance of goods liable to be re-used regularly, physical goods remain the preferred format for many interviewees, particularly because they are better depositories of attachment. Access to physical goods also leads to greater trust and an impression of being enduring. Finally, physical goods are also often preferred when it comes to giving or receiving gifts. 


\subsection{Physical purchases for repeated use}

ding to respondents, physical goods are rarely bought in consumption. Particularly for individuals who are used to using digital products, physical goods are no longer bought to discover new things but rather to return to content that is already familiar to the user, which they have already heard or seen. In the case of music, digital listening enables users to verify the quality of an album (Karpik 2007), while video streaming reassures them of the quality of a series or a film. The choice to purchase a physical version of the good occurs when there is little or no uncertainty as to the adequation between the goods and the consumer's tastes. Given the ease of access to many goods in digital format, those who have the "skills" will above all look for them in digital format ("Often, when I download a film it's because I don't know if it's really good. There are some I know will be good [...] And if it's really good, I'll watch it again, so I'll go buy it." Timothée, 32 years, sound engineer, 2 years post-secondary education). Acquiring digital goods, when they are purchased, can also respond to a desire to ensure long-term access to something that is important for the interviewee, even though the purchase of digital music is rare among interviewees.

The possibility of re-use or re-consumption is therefore often the driving force in buying a physical good, specifically because the item thus acquired is easy to use. Putting on a CD or a DVD is a task that is accessible to the vast majority of interviewees both in terms of skills and equipment. Digital goods enable consumers to avoid errors, poor purchases, or those that will be regretted because they were not useful. As a result, the physical goods that are purchased a purchased for good reason. Possession is a form of reassurance; it assures the consumer they will have access to this good when they need to. "No, it's really so I have it in material form, so I know I have it, and if I want to put it on I will, you know" (Ninon, 25 years, unemployed, two years postsecondary). But it is above all a way of accumulating personal assets that can then be displayed in the home. Physical acquisition is partly linked to the potential for reconsumption, which means certain goods are more likely than others to be bought, primarily those clearly belonging to popular culture. Their re-consumption is not a way of accumulating cultural capital but primarily a form of relaxation, escapism, or forgetting one's concerns.

Not all cultural areas are concerned by re-consumption in the same way. Generally, it seems music more often justifies the acquisition of a physical format - a CD might be listened to endlessly, but it is rarer that a DVD is watched over and over. This was explicit in Florence's comment 'because it's true that DVDs, when you've seen them once... CDs, good music, it's true you can listen lots of times. When I've seen a film, I won't watch it ten times." (51 years old, foster carer, middle school education).

For a given cultural area, there are also differences between the types of content. For example, DVDs of comedy shows or concerts might be more easily re-consumable than series or films. "So, yeah, DVDs I have three or four max [...] Given that of the three or four, two are of Florence Foresti ${ }^{3}$. That I might re-watch, in fact I think I already have." (Judith, 24 years old, bank employee, two years post-secondary). This kind of DVD can be put on in the background to be enjoyed alongside other activities.

But it is above all cultural goods "for children" that are concerned by physical purchases, particularly animated films and cartoons. The reason for this is that the propensity for them to be watched repeatedly is much higher and it is therefore more 
practical to have them on hand. Many of the DVD collections observed, where the individuals had children, contained a large section dedicated to content for young viewers. For some, the only DVD that were physically purchased were for children, who push for "obsessional", or at the very least regular, consumption. "Yeah, there's also the Disney ones, we have them because we like to re-watch them with Romane [her daughter]. But otherwise, no, we don't buy DVDs anymore." (Katia, 30 years, restaurant manager, middle school certificate).

There is a parallel to be made between the strong attachment to content for young people and the forms of very intensive consumption associated with "cult" followings or "fandom" for certain authors. Maigret (2002) for example, notes the fact that these cultural goods with "cult" status are primarily targeted at younger populations, children and young adults, and that the strong mobilisations, or intense attachment to certain works or worlds bear the mark of youth or popular culture. Indeed, even among young adults without children in this study, this type of content is often very present. It is for example the case of Théo (22 years old, student in art history, one year postsecondary), who not only collects VHS tapes but more particularly films produced by Disney, because of his particular attachment to the films watched during his childhood. In his $20 \mathrm{~m} 2$ apartment in Toulouse, shelves filled with tapes take up a large amount of room. These goods are comforting to him; he falls asleep at night to the sound of these videos he knows by heart.

The physical object thus has a reassuring aspect to it, particularly because it is permanently on hand, and reminds the viewer of moments they are attached to, both through the object itself but also its format and the way it is used. This is underlined in the analysis by Eva Illouz $(2006,2019)$, in the heritage of the Frankfort School (Adorno \& Horkheimer 1944) on the capitalism of emotions, and what she calls emodities - goods that are bought not for their content but for their ability to generate emotions.

We see this same logic in Julia (29 years, archivist, two years post-secondary) who, aside from active cultural consumption, particularly of arthouse cinema, reserves the purchase of physical goods for things related to her childhood. Once again this concerns Disney films, and others such as a film with Tom Hanks that she was particularly a fan of when she was younger, or series from the 90s and early 2000 s. "There was a time when I wanted to re-watch all the Disney films, I wanted to have everything with Tom Hanks, Forrest Gump and all that, and we bought them as they came out."

Film series are a case apart. DVD collections or boxed sets of Harry Potter, Lord of the Rings, Star Wars, Marvel, or the like are often on the shelves of these interviewees. "But well, I'm a great fan of Harry Potter, so I have all the DVDs of Harry Potter" (Yohann, 28 years, construction maintenance technician, 5 years post-secondary). In addition to the reassurance that comes with this juvenile consumption there seems to be a "series effect" linked to the satisfaction of having a full collection. "It's true that the only DVD's we buy are Marvel, and for me, Harry Potter or Fantastic Beasts. We don't buy many DVD's today, but those ones, we know we will... we've seen all of them four or five times each." (Chloé, 36 years, insurance agent, 3 years post-secondary). The degree of re-consumption of these films is very high and many interviewees have the habit of rewatching a given series of films in its entirety at regular intervals, at least once a year. This the case for James, for example (29 years, unemployed, 3 years post-secondary) who has DVDs of the long version of the Lord of the Rings and watches them at least 
once a year, and even deliberately limits these re-watchings to make the pleasure last longer. The same is true for Louise (26 years, employee in a hardware store, middle school certificate) and her husband who say they watch "everything in the full version", from Indiana Jones to Twilight. These "ensembles" are again an exceptional case and are often in specific formats such as collectors' editions, complete versions, director's cuts, or boxed sets. On this point Yohann (seen above) said "I'm a big fan of Doctor Who so I have a boxed set of Doctor Who. And the boxed set was really nice. I had bought the DVDs as they came out but I liked the box so I bought the full set as well." The boxed set in itself is important, because it is rarer, so it is "a little more" unique than other goods.

The idea of collection is clearly visible here. The fact that certain goods belong to an "ensemble" leads some interviewees to complete that ensemble. Buying the third part of a trilogy is justified because they have already bought the first two. As Baudrillard said, "the object attains exceptional value only by virtue of its absence" (Baudrillard 1996: 99). It thus seems that physical goods provide additional space for attachment, which stimulates a very strong affective dimension.

\subsection{Acquiring physical goods to have them reliably on hand}

35 The idea that certain physical formats are probably longer lasting than their digital equivalents is expressed frequently. The latter are seen as more fragile and more susceptible to technical malfunction, so buying physical goods is a way of investing in long term use. It is above all the older interviewees who appear concerned by this question, unlike younger respondents.

These arguments are similar to those concerning photographs, whose fate is often very dependent on the health of a computer and its likelihood to crash, which would mean losing its contents unless the necessary backups had been saved. in this respect, CDs, DVDs, vinyl records, video games in physical formats seem to be often considered better investments because they are more reassuring. What is particularly questioned is the digital format that is "saved" as a copy on a hard drive or any other digital device. The life span of these copies is dependent on that of the hardware on which they are stored, which makes them particularly fragile. And this is true even though the life span of a computer or a smartphone (or sometimes even its duration of use, the period for which it is actually used) is partly unknown.

"There is this impression, true or false, of how long it will last, which we don't yet know, DVD's are something will stay [...] I still have a bit of trouble with downloading, even with permanent downloads, because I am, if I remember, I had to buy something at the beginning a while ago, it was a game I think that I bought, and when I changed computers...pfffft [noise signifying that the content disappeared]". E4, Myriam, 32 years, press agent, 5 years post-secondary.

Many interviewees say they have trouble trusting content platforms. Physical goods that are stored in their houses are not dependent on the state of servers, or the terms of user licences on platforms; interviewees have more faith in the goods they possess physically. There are also doubts as to subscription conditions. In the case of video games, goods acquired through platforms like Steam are permanent (licences are bought not rented), but in the case of music and audiovisual content streaming the user retains nothing if the subscription expires. This seems to go against the logic of accumulation, "patrimonialisation" to use the term coined by Le Guern (2012), which is very present among older interviewees, which means they look for a lasting access 
without additional costs for goods already paid for. The low levels of knowledge of conditions of access and functioning of these platforms influences the (lack of) trust. This can be seen in James' comments:

"But, when I pay, I like to have the object and know that it's there and it's not something that is beyond me and which depends on technology that is completely beyond me, even though when I listen to a CD, it is out of my control, because if the thing breaks I won't know how to repair it. But at least I know where the CD is. I know where it is, I can listen to it when I want". E6, James, 29 years, unemployed, 3 years post-secondary.

Another concern, expressed by Ninon (who we saw above), is of having the contents disappear, primarily in a context where the resources used are above all illegal platforms, so the content is often deleted or added depending on copyright laws. Outside legal platforms, access to certain content can be sporadic, and it may be necessary to look on several platforms to find something, and there is no guarantee that a given film or TV series will still be available in a few weeks or months. Precarious access to certain cultural goods on digital platforms may incite consumers to turn to physical formats to guarantee preservation they see as more durable.

\subsection{Owning physical formats for sharing}

Finally, it is important to possess physical goods to be able to share them, which might seem paradoxical in the extent that digital media was specifically designed to improve the circulation of content and allow greater accessibility. Yet there is a lot of content that remains inaccessible if individuals do not have the right subscriptions or do no use a particular platform or do not wish to pay for certain goods. Particularly for goods that are not available for free, the physical "object" has a much greater importance than the digital version in exchanges and gifts between individuals.

"Really, there are films that I chose, for example Alexander, that came out. I went to see it twice in the cinema and I wanted to buy the DVD because... Phantom of the Opera. They are all films that are grandiose and deserve to be at home and like that we can share it with others". E37, Timothée, 32 years, sound engineer, technician, 2 years post-secondary.

The perspective of sharing is also what motivates certain individuals to keep particular cultural goods. "Owning them means you have them near you, you can lend them, or share them with people. That's what it is. I prefer to have them at home." (Jean, 20 years, fine arts student, secondary certificate). In this respect the difference from streaming platforms or online services is striking. If a film is on Netflix, the person we want to share it with must also have an account or find another way to view the film. Similarly, uncertainty about the availability of content on illegal streaming platforms is problematic for several interviewees who said they wanted to be sure they really owned certain works.

41 In terms of streaming practices, individuals can recommend albums or artists, leaving their correspondent to find a way to access that particular good, if they have the technical means to do so. By contrast, physical goods are easy to share - they can be loaned, borrowed, or given. And they are the object of particularly prestigious sociability, even when the exchanges are only planned - we keep them "just in case". This is the case for Theo, for whom the question of sharing is raised at several moments in the interview, for series, CDs, and for video games. 
"Yeah, yeah, I like to have them but not necessarily to watch them again right away. To have the set, be able to lend them, share that with someone, be able to say "here, watch this" [...] The idea of having it, keeping it, the video game, even if I don't play, it's like having an object. Maybe one day, I'll share it with someone. I think that's why I keep some of them". E30, Théo, 22 years, art history student, one year post-secondary.

Here we can see the distinction between the content that is associated with an individual (an account, a licence, a plan), and content that exists independently, and can be the object of exchanges, transactions, gifts etc. Nearly all the interviewees said was highly unlikely that they would give someone a downloaded album, but buying a CD or DVD was still a possible gift for many of them. Physical goods have a much higher symbolic value than digital goods.

\section{Recreating singularity through physical goods}

We have just seen the practical importance of having and using physical goods. But beyond this practicality, the importance of physical goods also lies in the fact that they are combined with specific experiences of consumption and use. Owning the CD the family used to listen to on long car trips, or an LP belonging to one's grandparents are cases where the cultural good itself takes on a singularity and meaning beyond the content itself. This singularity occurs primarily through the material-sensory nature of objects, and particularly their smell, texture, visual aspects, and place in the domestic space. We sometimes observe a form of "sacredness of objects" which is reminiscent of commodity fetichism (Marx 2009). In dispositionalist terms, this reflects an aesthetic relation to the world (Bakhtine et al. 1984; Lahire 2008) which focuses the analysis on a more limited number of interviewees with greater cultural capital and above all by the existence of a passion for culture.

Here we clearly observe a strong attachment for the formats available to individuals during their youth or childhood, which confirms the results from the qualitative data presented above. Respondents over 50 years old have a clear interest for records, whereas attachment to CDs, DVDs or boxed video games is much more common among those between 20 and 40 years old. Nostalgia genuinely has an impact, even for individuals who may not have experienced this particular format in its heyday. These formats may be imbued with history - real or imagined - linked to an individual's trajectory (or someone else's), and become unique because once they are produced physical goods take on a life of their own, unlike digital goods that cannot be unique or change, or take on history in themselves. For Mathis, for example, it is not the fact that Celine Dion represents an element of his childhood in general that matters, but the fact that it was this particular $C D$ that he listened to with his parents. Although the term singularisation was developed by Martuccelli (2005) as a revived form of the concept of differentiation, the term is used here not to refer to individuals but to the process though which mass-produced physical goods become unique, specific, imbued with meaningful attachment. We can then see the reflexive capacity of individuals who are able to choose content, format, and contexts for consumption that foster the expected effects.

We will see that the singularisation of an experience of consumption also occurs through the ritualisation associated with physical goods. For Goffman, ritualisation is characterised by the regularity of action, by distinct forms that make it stereotypical, 
and by the exaggeration of certain elements of the action (Goffman 1976; Winkin 2005). It is particularly this exaggeration, paying close attention to certain precise moments associated with the consumption of physical goods (opening the boxed set, carefully positioning the needle on an LP, etc.) that will contribute to the singularisation of this moment.

Using physical goods means conforming to certain constraints (opening a video game cover, inserting a disc into a player, listening to songs in the order on the album etc.) which leads to a certain frustration and to having to manage expectations, delay, and distance. This ritualisation aims to give meaning, tangibility, and weight to moments of acquisition and usage. It is all the more significant for individuals who are otherwise invested in digital consumption. Individuals also maintain their cultural passions and pleasures by recreating a form of inaccessibility, rarity.

\subsection{Singularity through the senses}

As Le Guern (2012) asks, "can an MP3 file still set its owner apart? And can music in digital format on a USB key or a hard drive still be fetichised?". The sentimental and sensorial aspect of physical formats is often mentioned in the interviews. The aesthetics of an LP jacket or a CD booklet, or how a boxed set looks in the home. This greater affinity for physical support is expressed through the senses, as Bartmanski and Woodward show for vinyl records (Bartmanski \& Woodward 2015). For many individuals who continue to acquire physical goods, in many respects the physical versions are seen as the "real" goods. They consider digital copies to be of lesser value, a kind of substitute for the physical goods, which they continue to use. Most of the time this substitute is sufficient, but it is seen by some as being not quite the "real thing". This is expressed in very vivid terms by Thomas:

"[Talking about a David Bowie LP] For me, if I listened to it on Spotify it would be a ... light version, like less good, you don't have the visual pleasure, you know, you don't have the charm, you don't have the content, just the essence, you know. You have the taste of lemon but not the lemon, you don't have the juiciness of lemon, you don't have the pips, it doesn't sting your eyes, you don't have all that, just the taste. Like lemon candy". E1, Thomas, 24 years, engineer, 5 years postsecondary.

Physical goods are also visible; by its simple presence, the object reminds individuals of itself. It is a source of satisfaction because of its aesthetics and its materiality in space. Attraction for visual elements, jackets, graphic design, is very clear. According to Chaney (2009), "the authenticity of a CD stems from the jacket, photos, dedications, song lyrics, that is the conditioning of the product [...] the packaging guarantees the origin and integrity of the product." This leads certain interviewees to acquire physical goods even though they no longer have the technical means to use them, simply because the object in itself fills an aesthetic or decorative function. "The object is beautiful. There is work in it. If you are interested in really how it is made, objects can be magnificent" (Jennifer, 30 years, medical secretary, high school certificate). Theo, for example, would like to buy the full collection of all the seasons of his favourite TV series, "when I have the money, not because I want to watch them. All the seasons, because the boxes are nice, it's a good edition, all that."

Beyond aesthetics, the value of physical goods comes from their presence in the domestic space. As Thomas explains, sometimes individuals "bump into" these objects or notice them. Their physical presence also allows a mental presence. ${ }^{4}$ 
"Yeah the object [the LP] it's important, even visually, because the album is enlarged, on the sleeve, with the drawing, and yeah, when I buy it and it's something I like, what I like is that the image kind of imposes itself on you a bit. Like, you'll put it in a corner and then you look away, and then you'll see the top of the blue record sleeve and you'll remember that it's there. Like it's waiting like "listen to me!" It's here, you know. [...] And you have the aesthetics of the sleeve like I said and I think that's really cool, even compared to a CD, a CD it's shiny, it gets dusty, it's... pointy, it hurts, a sleeve is cardboard, it's soft, it's warm, it's big, it's colourful". E1, Thomas, 24 years, engineer, Bac +5 .

Several interviewees use this metaphor of the "temperature" of the format, not just of the sound quality. Pierre for example says "records are warm. CDs are tepid, and digital tracks are completely cold. [...] And then when you get to de-materialised formats, sometimes it's like a flatline" (Pierre, 49 years, human resources manage in a train company, three years post-secondary). Other interviewees, such as Chantal (58 years, secretary in a non-profit, high school certificate) and Brigitte (66 years, secretary in the army, now retired, middle school certificate), talk about the "soul" of physical objects. We can clearly see a metaphor of the opposition between the living and the dead, which, beyond rhetorical expressions, clearly illustrates the difference in the way the interviewees experience physical and digital goods.

51 Originally identical to each other, physical goods progressively acquire a uniqueness an "aura" to use Benjamin's term (1939). For vinyl records, sound is produced through a mechanical effect and the object is transformed over time (it gets scratched or changes with temperature, etc.) and varies each time the needle passes over it, due to the imperfections in the surface. CDs seem less "vulnerable" than records, and less subject to these micro-changes. As for digital files, they are near-unalterable. Mathis expresses this in his comment below, emphasizing the fact that this singularity can have a direct impact on the way a piece is played on the record player. This is precisely the creation of the "here and now" (Benjamin 2008); the uniqueness of the moment.

"I think it's the mechanical aspect that I like. The fact that, not imperfect, but a sound that is a little more, I don't know, it gives it a more authentic feel, the fact that it is vulnerable, if there's a little bit of dust it will crackle, it's mechanical sound, you know". E19, Mathis, 30 years, social assistant, two years post-secondary.

Similarly, Jonathan describes certain specificities of the CD format, with its constraints and its limits, but also its pleasures. The vulnerability of these formats means they must be looked after carefully. Choosing to continue to buy and mobilise physical goods also means accepting to take care of certain objects that may deteriorate over time. CDs can get scratched, VHS can get de-magnetised, record sleeves can fade in the sun. This vulnerability means dedicating time and attention to maintain them in a decent condition.

"You know with the old cases which were transparent plastic, but the plastic had faded, well, the booklet corners are bent, you anxiously look to see on the other side to see if it's not too scratched, if it can be played, or you spray a little window cleaner hoping it will remove the scratches [he seems disillusioned]". E2, Jonathan, 30 years old, project manager TF1, 5 years post-secondary.

These objects are part of the familiar sphere, of what is known. We are used to them, we recognise them, particularly through their alterations over time. These modifications give them their identity, a uniqueness that contributes to the satisfaction the individual has in using or consuming them. 


\subsection{Singularity through the ritualisation of moments of acquisition and consumption}

Fig. 3.

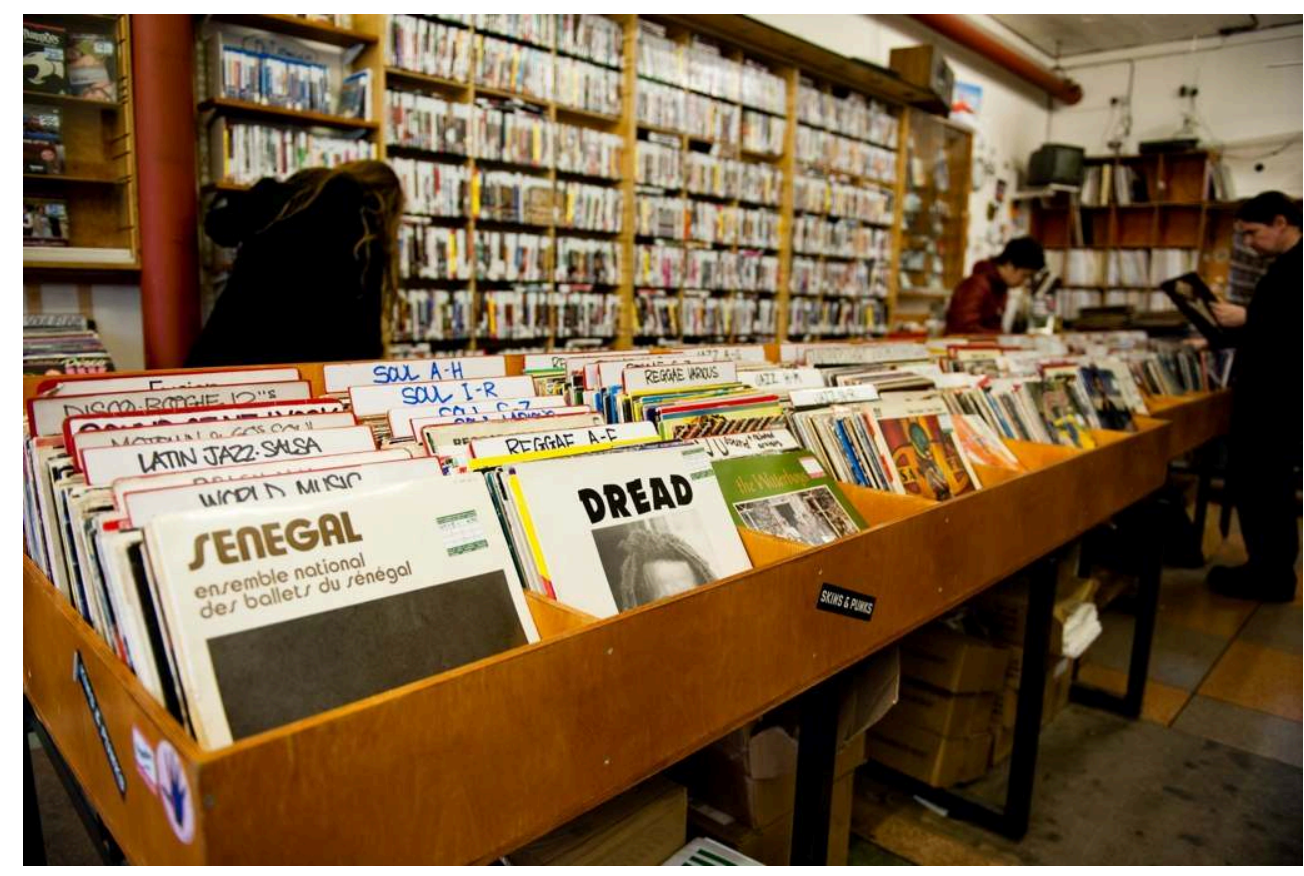

Vinyl Heaven

(C) Matthias Rhomberg. Licence CC BY 2.0

54 We will now see that not only are these physical goods cherished for their sensory characteristics, but they also are subject to a strong ritualisation of practices. This is particularly true for those who are the most committed to cultural goods, but whose relationship with aesthetics might be directed at goods that are highly legitimate (arthouse cinema, classical music) or goods that lack cultural legitimacy (animated films, video games, variety music, etc.). Because they respond to technical constraints and are less easily accessible, these goods are more costly to mobilise. Once again, this additional effort often serves an aesthetic relationship with the goods in which constraint increases satisfaction.

This ritualization primarily occurs through the difficulties associated with acquiring them. Because they are not immediately accessible, unlike cultural goods accessed through streaming or downloading, for example, they require an organisation and visits to shops or delivery time. Their rarity encourages emotional investment, which can be seen in other studies conducted particularly on the aesthetic experience of digital music (Hanrahan 2018). Being obliged to delay access to goods is often seen as a way of maintaining a certain frustration and thus excitement when the object is finally obtained. Among intensive consumers of streaming content, we therefore observe a certain nostalgia for these forms of acquisition that allow for anticipation and delayed pleasure.

"There is something like that of course... well to have a game, you had to, when I was younger, it had to be a special occasion, like a birthday or Christmas, or the result of pretty major nagging, which made the victory at least as ... really exquisite 
because it was the result of repeated frustration to have something. [...] That ease of acquisition, maybe it loses its charm and so it reduces its intrinsic value." E2, Jonathan, 30 years, project manager TF1, 5 years post-secondary.

56 Jonathan is a big consumer of digital content, whether music, film, series, or video games, but he still buys physical goods in certain instances, particularly for things he has an emotional connexion to. Some individuals find themselves recreating rarity by establishing constraints that they know to be illusions, but which they are attached to, in order to increase their frustration and thus their long-term pleasure. Having almost instant access to a plethora of cultural content sometimes lessons the satisfaction in watching or listening to it. The construction of pleasure also occurs through the period of anticipation which enables imagination and the projection of oneself in consumption. An important aspect of the pleasure of cultural consumption thus takes place in advance - it is the perspective of receiving, acquiring, or consuming which feeds this satisfaction. Establishing constraints and maintaining distance allows for the prolongation of this satisfaction through anticipation. For certain interviewees, this satisfaction was even greater than that derived from the consumption itself.

"I never liked video games as much as when I had the fewest of them. At the time when I had one game every three months, I was a total fan. And now, when I have a bit more money, and I can buy all the video games I likem I get bored quickly, I don't finish the games or I don't even start them". E30, Théo, 22 years, art history student, 1 year post-secondary.

57 This was also the case for Jean who recounted how he used to borrow videos from a video club which maintained a certain excitement and satisfaction that he misses a little today. It was not so much the physical or material nature of the format in this case as the difficulty in access and the creation of an expectation that was not immediately satisfied. "It was going to get the tape, putting it in the machine. There was something exciting about that. There was something more exciting than when you download it ..." (Jean, 20 years, fine arts student in Paris, high school certificate).

Physical goods are also used in specific contexts. Firstly, they foster attentive consumption, almost by constraint. Particularly in the case of records and CDs, the constraints associated with these formats encourage users to respect the integrity of the album. Individuals will "relax" and often make themselves available to listen even if that doesn't exclude doing other activities at the same time. These formats are therefore used at times that encourage a certain attention to the work. This is also the opportunity to demonstrate a formalism in consumption. We might prepare food and drink in advance so that we don't have to get up, take the object out of its box, put it in the player and so forth.

"Before, when I had a bathtub, I used to like, I would put on Agnès Obel and I would listen to the whole CD and take my bath like that. [...] And I think that with records that's even more the case, because you leave the record on, but record players are a bit more expensive. I think I would have one, but the pleasure is in really deeply listening". E21, Julia, 29 years, archivist, two years post-secondary.

Similarly, ritualised consumption of certain audio-visual content is marked by this idea of "respect" and attention. When Sébastien, Mathilde, Timothée, Thomas and others say they watch all of the Lord of the Rings, particularly the collectors' editions, the act of putting the DVD in the player, "preparing the screening", choosing the right settings, sometimes going through the booklet, etc. are all forms of preparation. These moments allow them to respect the "requirement for unity" (Hennion et al. 2000) of 
cultural goods, in particular the integrity of the album, respecting the order of the tracks as they were intended by the creators:

"I realised not long ago that going back to listening to CDs on my HI-FI, without being connected to a platform, meant that I actually listened to the CD, I didn't switch, and it did me good. That's something I like, I don't know how to explain it, perhaps because I was brought up in a family where music was recognised, I'll put it like that, and so it's something that I like to do and I realised that I don't do it anymore and that I missed it. And when I wasn't doing it, I didn't even realise. And doing it again I realised it was a pleasure that I don't allow myself often enough. And it is a real pleasure". E19, Mathis, 30 years, social assistant, two years postsecondary.

In itself, preparing for attentive consumption might be part of the ordinary experience of cultural goods, but it is the particular meaning of this practice for individuals who have high levels of consumption of digital goods that is particularly interesting. As the consumption of different reproducible cultural goods is constantly increasing, the heterogeneity of available formats allows individuals to vary their pleasures by using cultural goods to create "moments" that are unique, suspended in time. The interviewees seem to often emphasize an inverse relationship between the "charm" of particular formats and how practical they are. This means taking the time to pay full attention to the object. Because the physical object has become unique, because it exists independently, the consumer experience is also affected by this.

\section{Conclusion}

The ongoing use of physical cultural goods may come as a surprise given that digital goods seem to have progressively dominated the market for media-cultural goods. Yet physical goods continue to be used because their characteristics contribute to the pleasure of consumption. Physical goods provide unquestionable advantages for many interviewees, particularly in terms of accessibility, security, and circulation. They are the proof that particular content is genuinely owned, that it is available and on hand. But beyond these advantages, individuals also use physical goods to obtain a certain singularity of experience. Digital goods are standardised so it is impossible to distinguish the copy of a digital file from another copy; they do not age, they do not acquire singularity with time, they cannot be unique. Physical goods specifically allow this singularity this "here and now", to use Walter Benjamin's terms (2008). Physical goods may be used only rarely, from time to time, but nevertheless be highly significant for individuals, and even more so when they use digital formats on an everyday basis. Individuals themselves seek to (re)discover a unique experience through consumption by reinserting rarity and sometimes even certain forms of frustration, or deliberately perpetuating distance from certain cultural goods. They thus recreate singularity both through the sensory aspect of physical goods and by the ritualisation of these moments of acquisition (returning to a particular store, browsing etc.) and of consumption. 


\section{BIBLIOGRAPHY}

ADORNO Theodor W. \& HORKHEIMER Max (2016) [1944]. Dialectic of enlightenment. English translation by Edmund Jephcott. London, Verso Books.

BAKHTINE Mikhaïl (1984). Esthétique de la création verbale. Translated by Alfreda Aucouturier. Paris, Gallimard.

BARTMANSKI Dominik \& WOODWARD Ian (2015). “The Vinyl: The Analogue Medium in the Age of Digital Reproduction.” Journal of Consumer Culture, 15(1): 3-27.

BAUDRILLARD Jean (1996) [1968]. The System of Objects. London/New York, Verso.

BENJAMIN Walter (2008) [1935]. The Work of Art in the Age of Mechanical Reproduction. English translation by J.A. Underwood. London, Penguin.

BEUSCART Jean-Samuel (2017). “A la recherche de la découverte musicale. Une exploration du 'régime exploratoire'." In Dominique Pasquier (ed.). Explorations numériques. Hommages aux travaux de Nicolas Auray. Paris, Presses des Mines.

BOURDIEU Pierre (1987) [1979]. Distinction: A Social Critique of the Judgment of Taste. English translation by Richard Nice. Cambridge, Cambridge University Press.

CERTEAU Michel (de) (2011) [1990]. The practice of everyday life. English translation by Steven Rendell. Berkeley, University of California Press.

CHANEY Damien (2009). "Pourquoi acheter un CD quand on peut le télécharger? Une approche exploratoire par le concept d'appropriation." Management \& Avenir, 20: 30-48.

CHANTEPIE Philippe (2017). “L'accès illimité ou l'impossession culturelle?”. Nectart, 1: 137-146.

COULANGEON Philippe (2011). Les Métamorphoses de la distinction. Paris, Grasset.

ELoY Florence (2014). "Le rapport des élèves de milieux favorisés à la culture scolaire.” Agora débats/jeunesses, 66(1): 77-90.

ELOY Florence (2015). Enseigner la musique au collège. Cultures juvéniles et culture scolaire. Paris, Presses Universitaires de France.

GFK (2020). « Baromètre CNC-GfK 2019 de la vidéo physique ». [Accessed on 9 June 2020].

GFK (2019). « Baromètre CNC-GfK de la vidéo physique 2018 ». [Accessed on 9 juin 2020].

GLEVAREC Hervé (2005). "La fin du modèle classique de la légitimité culturelle. Hétérogénéisation des ordres de légitimité et régime contemporain de justice culturelle. L'exemple du champ musical." In MAIGRET Eric \& MACÉ Eric (eds.). Penser les médiacultures. Nouvelles pratiques et nouvelles approches de la représentation du monde. Paris, Armand Colin/INA: 69/102. [Accessed on 19 juin 2015].

GLEVAREC Hervé \& PINET Michel (2013). "Principes de structuration des pratiques culturelles : stratification et âge." Revue européenne des sciences sociales, 51-1: 121-152.

GOFFMAN Erving (1976). "Social Interaction, Ritualizations and displays." Course given at the University of Pennsylvania, Department of Anthropology. Pensylvanie.

GRANJON Fabien \& COMBES Clément (2008). "La numérimorphose des pratiques de consommation musicale." Réseaux, 145-146: 291-334. 
GUITTET Emmanuelle (2020). “'Me-I Need Paper' Analysis of Novel Readers' Difficult and Unequal Adoption of the Digital Format." Biens symboliques/Symbolic goods, 7.

HANRAHAN Nancy Weiss (2018). "Hearing the Contradictions: Aesthetic Experience, Music and Digitization." Cultural Sociology, 12(3): 289-302.

HENNION Antoine (2004). “Une sociologie des attachements.” Sociétés, 85(3): 9-24.

HENNION Antoine (2009). “Réflexivités. L'activité de l'amateur.” Réseaux, 153: 55-78.

HENNION Antoine, MAISONNEUVE Sophie, GOMART Émilie (2000). Figures de l'amateur: formes, objets, pratiques de l'amour de la musique aujourd'hui. Paris, La Documentation Française.

ILLOUZ Eva (2006). Les Sentiments du capitalisme. Paris, Seuil.

ILLOUZ Eva (2019). Les Marchandises émotionnelles. Paris, Premier Parallèle.

KARPIK Lucien (2007). L'Économie des singularités. Paris, Gallimard.

LAHIRE Bernard (2006). La Culture des individus. Dissonances culturelles et distinction de soi. Paris, la Découverte.

LAHIRE Bernard (2008). La Raison scolaire. École et pratiques d'écriture, entre savoir et pouvoir. Rennes, Presses Universitaires de Rennes.

LAHIRE Bernard (ed.) (2019). Enfances de classe. De l'inégalité parmi les enfants. Paris, Seuil.

LE BECHEC Mariannig, CREPEL Maxime, BOULLIER Dominique (2014). "Modes de circulation du livre sur les réseaux numériques.” Études de communication, 43: 129-144.

LE GUERN Philippe (2012). "Irréversible : Musique et technologies en régime numérique." Réseaux, 2: 29-64.

LE GUERN Philippe (2016). Où va la musique? Numérimorphose et nouvelles expériences d'écoute. Paris, Presses des mines.

LEGAULT-VENNE Ariane, LAPLANTE Audrey, LEBLANC-PRoulX Sébastien, FOREST Dominic (2016). “Du vinyle à YouTube: les habitudes de consommation et de recherche de musique des jeunes adultes québécois." Partnership: The Canadian Journal of Library and Information Practice and Research, 11(2). LEMIEUX Cyril (2009). Le Devoir et la Grace. Paris, Economica.

LEMIEUX Cyril (2018). La Sociologie pragmatique. Paris, La Découverte. [Accessed on 26 juillet 2019]. MAGAUDDA Paolo (2011). “When Materiality 'Bites Back’: Digital Music Consumption Practices in the Age of Dematerialization.” Journal of Consumer Culture, 11(1): 15-36.

MAIGRET Éric (2002). "Du mythe au culte... ou de charybde en scylla? Le problème de l'importation des concepts religieux dans l'étude des publics des médias." In LE GUERN Philippe (ed.) Les cultes médiatiques: Culture fan et œuvres cultes. Rennes, Presses Universitaires de Rennes: 97-110.

MARTUCCELLi Danilo (2010). La Société singulariste. Paris, Armand Colin.

MARX Karl (2009) [1867]. Le Capital. Livre I. Paris, Folio.

MAUGER Gérard, POLIAK Claude, PUDAL Bernard (2010) [1999]. Histoires de lecteurs. Bellecombe-enBauges, Éditions du Croquant.

NGUYEN Godefroy Dang, DEJEAN Sylvain, MOREAU François (2014). "On the complementarity between online and offline music consumption: the case of free streaming." Journal of Cultural Economics, 38: 315-330. 
OCTOBRE Sylvie (2014). "Les enfants du numérique : mutations culturelles et mutations sociales." Informations sociales, 181: 50-60.

OCTOBRE Sylvie \& BERTHOMIER Nathalie (2012). "Socialisation et pratiques culturelles des frères et sœurs." Informations sociales, 173(5): 49-58.

OCTOBRE Sylvie, DETREZ Christine, MERCKLE Pierre, BERTHOMIER Nathalie (2011). "La diversification des formes de la transmission culturelle : quelques éléments de réflexion à partir d'une enquête longitudinale sur les pratiques culturelles des adolescents." Recherches familiales, 8: 71-80.

PASQUIER Dominique (2005). Cultures Lycéennes. La tyrannie de la majorité. Paris, Autrement.

PERTICOZ Lucien (2009). Les Processus techniques et les mutations de l'industrie musicale : l'auditeur au quotidien, une dynamique de changement. $\mathrm{PhD}$ thesis in Information and Communication Sciences. Grenoble, Université Stendhal.

PETERSON Richard (2004). "Le passage à des goûts omnivores : notions, faits et perspectives." Sociologie et sociétés, 36(1): 145-164.

PETROVER Benjamin (2015). Ils ont tué mon disque ! Paris, First.

PRIOR Nick (2012). “Musiques populaires en régime numérique.” Réseaux, 172.

SNEP (2019). Bilan 2018 du marché de la musique enregistrée. Rubrique "News". [Accessed on 27 March 2020].

WINKIN Yves (2005). “La notion de rituel chez Goffman. De la cérémonie à la séquence.” Hermès, La Revue, 43(3): 69-76.

\section{NOTES}

1. See my PhD for a more detailed presentation of MCA and clustering (Gilliotte, 2019).

2. Moreover, the impact of gender also which varies greatly according to format. Men, for example, are much more inclined to be attached to vinyl records than women ( $18 \%$ compared to $9 \%$ ), while women are over-represented among individuals who are attached to books (52\% compared to $36 \%$ for men). There are few differences between the sexes for CDs or DVDs/BluRay, however.

3. A famous French humorist and comedian.

4. My PhD research also explores how individuals create architectures of attention, in other words, ways of organising physical and digital goods that allow the individual to more easily manage their attention. Another part of this research is entirely dedicated to the importance of the visibility of cultural goods in the domestic space, both for the self (constructing a representation of the self in relation to one's collection of cultural goods) and for others (what is presented or on display ). 


\section{ABSTRACTS}

Drawing on sixty interviews conducted around France, and a quantitative quota-based study with 2000 respondents, this article shows why there is a "persisting" use of physical cultural goods (CDs, DVDs, vinyl records, boxed video games, etc.). On the one hand, these physical goods have "practical" advantages which mean they are easier for many respondents to use and re-use on an everyday basis, to have nearby, and to share with others. On the other, these goods entail constraints that have been made virtues, and which contribute to the pleasure of their use, recreating the rarity and singularity in the consumer experience. This singularity is primarily based in a sensory relationship to cultural goods (through smell, touch, place in domestic space) and through forms of ritual associated with moments of acquisition or consumption.

À partir d'une soixantaine d'entretiens menés un peu partout en France et d'une enquête quantitative par méthode des quotas auprès de plus de 2000 répondants, l'article montre pourquoi il y a une "persistance » du recours aux biens culturels physiques (CD, DVD, vinyles, jeux vidéo en boite etc.). D'une part, ces supports physiques présentent des avantages « pratiques ", faisant qu'ils sont pour beaucoup d'enquêtés plus faciles à mobiliser au quotidien, pour les reconsommer, les avoir à portée de main, mais également pour les faire circuler. D'autre part, ces biens présentent également un certain nombre de contraintes faites vertus, qui viennent alimenter le plaisir et permettent de recréer de la rareté, de la singularité dans l'expérience de consommation. Cette singularisation passe en priorité par un rapport sensible aux biens culturels (par le toucher, l'odeur, la place prise au sein de l'espace domestique) et par des formes de ritualisation des moments d'acquisition et de consommation.

\section{AUTHORS}

\section{QUENTIN GILLIOTTE}

Université de Paris/Centre de recherche sur les liens sociaux (Cerlis) 